\title{
Jędrzej Chumiński
}

Uniwersytet Ekonomiczny we Wrocławiu

e-mail: jedrzej.chuminski@ue.wroc.pl

\section{WPLYW REFORMY ROLNEJ W POLSCE NA MOBILNOŚĆ LUDNOŚCI WIEJSKIEJ W LATACH 1944-1956}

\section{INFLUENCE OF LAND REFORM IN POLAND ON THE MOBILITY OF RURAL POPULATION IN THE YEARS 1944-1956}

DOI: $10.15611 /$ sie.2018.1.01

Streszczenie: Jednym z najważniejszych problemów społecznych i gospodarczych II Rzeczypospolitej było agrarne przeludnienie wsi. Jego skutkiem było zjawisko „ukrytego bezrobocia". Problem przeludnienia agrarnego pozostał istotny także w czasach rządów komunistów w Polsce po 1944 r. Warto zatem zadać pytanie, jakie czynniki wpływały na skale tego zjawiska po wojnie: w jakim stopniu zostało ono ograniczone przez przyjętą we wrześniu 1944 r. reformę rolną, prowadzoną przez władzę politykę intensywnej industrializacji i związane z nią masowe migracje ludności wiejskiej do miast. Kluczowym problemem jest również ocena ekonomicznej efektywności migracji. Analiza pozwala na sformułowanie wniosku, że kształt przeprowadzonej we wrześniu 1944 r. reformy rolnej miał istotny wpływ na długofalowe zacofanie polskiej wsi.

Słowa kluczowe: reforma rolna, mobilność ludności wiejskiej, PRL, przemysł.

Summary: One of the most important social and economic problems of the Second Polish Republic was the agrarian overpopulation in rural areas. It resulted in the phenomenon of "hidden unemployment". The problem of agrarian overpopulation remained significant also during the communist rule in Poland after 1944. It is worth asking a question what factors influenced the scale of this phenomenon after the war: to what extent it was limited by the agricultural reform adopted in September 1944, the policy of intensive industrialization pursued by the authorities and, related to it, mass migration of rural population to cities. The assessment of the economic effectiveness of migration is also a key problem. The analysis allows to formulate conclusion, that the shape of the land reform carried out in September 1944 had a significant impact on the long-term backwardness of the rural areas in Poland.

Keywords: agrarian reform, mobility of rural population, People's Republic of Poland, industry. 


\section{Wstęp}

Jednym z najważniejszych problemów społecznych i gospodarczych II Rzeczypospolitej było agrarne przeludnienie wsi. Jego skutkiem było zjawisko „ukrytego bezrobocia”, które oznacza, że „usunięcie z wykorzystywanej kombinacji czynników pewnej liczby jednostek pracy nie powoduje zmniejszenia wielkości produkcji lub powoduje nawet jej zwiększenie"1. Trzeba przy tym podkreślić, że przedwojenne szacunki skali tego zjawiska były bardzo zróżnicowane. Część autorów uwzględniała bowiem w swoich obliczeniach tzw. przeludnienie względne ( $\mathrm{tj}$. takie, jakie by wystąpiło, gdyby przyjąć normy zatrudnienia w krajach wysoko rozwiniętych), inni zaś ograniczali się do szacowania bezrobocia bezwzględnego (tj. występującego przy istniejącej strukturze rolnictwa). Stąd rozbieżność szacunków: od 2,4 $\mathrm{mln}$ do $8,8 \mathrm{mln}$ osób. Te ostatnie obliczenia J. Poniatowskiego oznaczały, że ukryte bezrobocie wynosiło ok. 40\% ludności mieszkającej na wsi, a w województwach centralnych i południowych, gdzie było największe, stanowiło ponad 50\% ludności rolniczej $^{2}$. Bardziej miarodajne (tak twierdził choćby M. Mieszczankowski) wydają się jednak obliczenia Instytutu Gospodarstwa Społecznego, który w latach 1934-1935 przeprowadził badania w 53 wsiach i na tej podstawie oszacował bezwzględne ukryte bezrobocie na 2371 tys. osób, w tym 1529 tys. mężczyzn i 842 tys. kobiet. Oznaczało to, że w grupie ludności wiejskiej w wieku 15-59 lat ludzie zbędni stanowili $18,1 \%$. Największe było w województwach: krakowskim - 21,4\%, lwowskim $24,1 \%$, stanisławowskim - 24,5\% i tarnopolskim - 21,5\%. W liczbach bezwzględnych największa liczba dotyczyła województw: lwowskiego - 318 tys. osób, kieleckiego - 242 tys., lubelskiego -240 tys. i krakowskiego -202 tys. $^{3}$

Problem przeludnienia agrarnego wsi pozostał istotny także w czasach rządów komunistów w Polsce po 1944 r. Warto zatem zadać pytania: jakie czynniki wpływały na skalę tego zjawiska po wojnie i w jakim stopniu zostało ono ograniczone przez przyjętą we wrześniu 1944 r. reformę rolną, prowadzoną przez władzę politykę intensywnej industrializacji i związaną z nią masową migrację ludności wiejskiej do miast? Kluczowym problemem jest również ocena ekonomicznej efektywności migracji, i to zarówno dla polskiej wsi, jak i dla działów gospodarki, do której trafiali chłopscy migranci. W tym ostatnim przypadku występujące problemy zilustrujemy sytuacją przemysłu, w którym znalazła zatrudnienie większość osiedlających się w mieście chłopów.

${ }^{1}$ M. Góra, M. Rutkowski, Popyt na pracę oraz bezrobocie ukryte w Polsce w latach 1980-ych, Ekonomista 1990, nr 2-3, s. 421.

2 A. Jarosz-Nojszewska, Józef Maria Poniatowski i ,, Gospodarka Narodowa”, Gospodarka Narodowa 2011, R. LXXX/XXI nr 5-6 (237-238), s. 129.

3 A. Gawryszewski, Ludność Polski w XX wieku, PAN, Warszawa 2005, s. 369, 370. 


\section{Czynniki wpływające na migrację ludności wiejskiej do miast}

Wojna w zasadniczy sposób zmieniła strukturę terytorialną i demograficzną Polski. Ze względu głównie na straty ludnościowe i zmiany terytorialne liczba mieszkańców kraju zmniejszyła się o ok. 11,2 mln osób (wg szacunków z 1939 r. wynosiła $35,1 \mathrm{mln}$, natomiast w 1946 r. 23,9 mln), a gdyby uwzględnić prognozy wzrostu zaludnienia, to straty sięgały nawet $14,2 \mathrm{mln}^{4}$. O tak głębokim spadku zadecydowało przede wszystkim zmniejszenie się liczby ludności wiejskiej, mimo że ofiary w tej grupie były stosunkowo niewielkie (1272 tys. zabitych, czyli ok. $21 \%$ ogółu) $)^{5}$. Porównanie liczby mieszkańców wsi według spisu z 1931 r. i lutego 1946 r. świadczy, że była ona po wojnie niższa o 7076 tys. (ludność miejska zmniejszyła się o 1214 tys.). Oznacza to, że udział ludności wiejskiej obniżył się po wojnie z 72,6 do $68,2 \%$, a ludności miejskiej wzrósł z 27,4 do 31,8\% ${ }^{6}$.

Szansę na rozwiązanie przeludnienia agrarnego stanowiło także przejęcie przez Polskę lepiej zurbanizowanych wschodnich terenów III Rzeszy. Znajdowały się tam bowiem w 1939 r. 263 miasta, które zamieszkiwało 4250 tys. osób, a na obszarach zabranych Polsce przez Związek Radziecki zlokalizowane były 164 miasta liczące 2198 tys. mieszkańców. Oznacza to, że na powojennym terytorium Polski przed wojną znajdowały się 704 miasta, które zamieszkiwało 12045 tys. osób. Według danych z 1939 r. na terytorium II Rzeczypospolitej znajdowało się 609 miast z 9896 tys. mieszkańcami. Zwiększyło to miejską chłonność osadniczą o przeszło $2 \mathrm{mln}$ osób (oczywiście rzeczywiste określenie zapotrzebowania wymagałoby uwzględnienia zniszczeń wojennych i strat ludnościowych) ${ }^{7}$. Skalę problemów z zasiedleniem po wojnie miast ilustruje fakt, że w lutym 1946 r. zamieszkiwało je zaledwie 7376 tys. mieszkańców, czyli ponad 4,5 mln mniej niż w 1939 r.

Jednocześnie od początku też uznawano, że poważnym problemem będzie znalezienie odpowiedniej liczby osadników w miastach zlokalizowanych na tzw. Ziemiach Odzyskanych. E. Romer na posiedzeniach Rady Naukowej dla Zagadnień Ziem Odzyskanych wręcz proponował ograniczenie osadnictwa miejskiego, jak mówił: ,Jeżeli było tam $60 \%$ czy $70 \%$ ludności miejskiej, to teraz będzie $30 \%$ i przez to korona z głowy Polsce nie spadnie. Nie będziemy więc potrzebowali na zaludnienie miast $4 \mathrm{mln}$, ale wystarczy 2" ${ }^{\text {. W }}$ opracowanym zaś w maju 1945 r. planie osadnictwa maksymalną rezerwę ludności miejskiej, która mogła zostać przesiedlona na

${ }^{4}$ K.J. Latuch, Straty demograficzne Polski w latach 1939-1945 (z prac nad weryfikacja oficjalnych szacunków), Polska 1939-1945. Straty osobowe i ofiary represji pod dwiema okupacjami, IPN, Warszawa 2009, s. 40, 41.

${ }^{5}$ W. Jakubowski, Chłopi polscy 1944-1948. Perspektywa psychohistoryczna, Instytut Nauk Politycznych Uniwersytetu Warszawskiego i Wyższa Szkoła Humanistyczna w Pułtusku, Pułtusk-Warszawa 2000 , s. 35.

${ }^{6}$ Historia Polski w liczbach. Państwo i społeczeństwo, T. I, GUS, Warszawa 2003, s. 359, 369.

A. Gawryszewski, Ludność Polski..., s. 119-125.

8 Wystapienie E. Romera na I Sesji RNdZZO (30 lipca - 1 sierpnia 1945 r.), Archiwum Akt Nowych (dalej: AAN), Ministerstwo Ziem Odzyskanych (dalej: MZO), sygn. 1682, s. 48. 
tzw. Ziemie Odzyskane, oszacowano na 1793,6 tys. (w tym 423 tys. z kresów wschodnich, 100 tys. repatriantów z głębi ZSRR, 500 tys. z Warszawy i 770,6 tys. osób z innych miast Polski) ${ }^{9}$.

Przeobrażenia będące zatem konsekwencją wojny stwarzały ludności wiejskiej duże możliwości migracji do miast. Zjawisko to należy jednak także widzieć w kontekście ogólnych wzmożonych ruchów ludnościowych po wojnie. Według szacunków A. Gawryszewskiego w latach 1946-1950 migracje wewnętrzne objęly 7124 tys. osób, a w latach 1951-1955 6898,4 tys. osób (dane te oparte są na statystyce meldunkowej i są oczywiście o wiele wyższe niż rzeczywista skala migracji ${ }^{10}$. Według szacunkowych danych w latach 1946-1950 przeniosło się ze wsi do miast ok. 1,2 mln osób (tzn. rocznie przeciętnie 240 tys. osób), a w latach 1951-1960 dalszych $1,3 \mathrm{mln}$ (rocznie 130 tys.). W sumie zatem w latach 1945-1960 migrowało ze wsi do miast ok. 2,5 mln osób ${ }^{11}$.

Warto w kontekście tych danych rozważyć, w jakim stopniu uchwalona we wrześniu 1944 r. reforma rolna sprzyjała zwiększeniu mobilności ludności wiejskiej i jak przyjęte w niej rozwiązania wpłynęły na sytuację społeczną i gospodarczą Polski. Wydaje się bowiem, że kształt przyjętych wówczas rozstrzygnięć był jednym z głównych czynników utrzymującego się przez cały okres PRL zacofania rolnictwa i niskiej efektywności przemysłu.

Zasadniczą wadą reformy było utrwalenie, a nawet pogorszenie struktury agrarnej polskiego rolnictwa. Nie zlikwidowano bowiem najpoważniejszej jego słabości, tj. rozdrobnienia agrarnego (likwidując przy okazji duże, najbardziej towarowe, gospodarstwa). Wynikało to z przyjętej z powodów politycznych zasady preferowania bezrolnych i małorolnych. W efekcie powstało 814 tys. nowych gospodarstw (w tym na tzw. ZO 466,9 tys.), powiększono zaś 254,4 tys. Oznacza to, że ok. 30\% istniejących gospodarstw skorzystało z dobrodziejstw reformy. Jej efektem zaś było utrzymanie bardzo licznej grupy gospodarstw karłowatych i małorolnych (gospodarstw poniżej 5 ha w 1950 r. było 1813,1 tys., tj. 57,2\%). Co gorsza, w okresie planu sześcioletniego ich liczba zdecydowanie wzrosła. W 1957 r. gospodarstw do 5 ha było już 2302,1 tys., czyli $63,4 \%{ }^{12}$. Warto podkreślić, że przy ówczesnym wyposażeniu technicznym za zdolne do funkcjonowania uważano gospodarstwa powyżej 5 ha. W 1950 r. średnia powierzchnia gospodarstwa liczyła zaledwie 5,3 ha, a w $1970 \mathrm{r}$. spadła nawet do 4,7 ha. Mało tego, niemal do końca PRL zaledwie 33\% gruntów

9 J. Chumiński, Koncepcje rozwiązania problemów ludnościowych i przebieg zasiedlenia Wrocławia w latach 1945-1949, Przegląd Zachodniopomorski 1995, R. X (XXXIX), z. 1, s. 113.

${ }^{10}$ A. Gawryszewski, Przestrzenna ruchliwość ludności Polski 1952-1985, Ossolineum, Wrocław 1989, s. 26. Między danymi w pracach A. Gawryszewskiego istnieją niewielkie różnice w liczbie osób migrujących w latach 1951-1955.

${ }_{11}$ M. Pohoski, Migracje ze wsi do miast. Studium wychodźstwa w latach 1945-1957 oparte na wynikach ankiety Instytutu Ekonomiki Rolnej, PWE, Warszawa 1963, s. 53.

12 Rocznik Statystyczny 1956, GUS, Warszawa 1956, s. 149; Rocznik Statystyczny 1958, GUS, Warszawa 1958, s. 140; M. Pohoski, wyd. cyt., s. 214. 
znajdowało się w posiadaniu gospodarstw indywidualnych, których obszar przekraczał 10 ha $^{13}$.

Negatywne skutki takiej struktury agrarnej są widoczne zwłaszcza w dłuższej perspektywie czasu. Paradoksalnie bowiem przy minimalnych nakładach inwestycyjnych w rolnictwo prywatne bardzo szybko skończyła się sytuacja, w której odpływ ludności wiejskiej wymagał zerowych kosztów substytucji ${ }^{14}$. Karłowate gospodarstwa nie były w stanie generować zysku, który mógł być przeznaczony na ich rozwój. Problem dodatkowo pogłębiała polityka władz wyraźnie upośledzająca rolnictwo (zwłaszcza prywatne). W planie sześcioletnim, przy ogólnie bardzo niskim udziale tego działu gospodarki narodowej w wydatkach inwestycyjnych (zaledwie $10 \%$, na przemysł wydatkowano $44,4 \%$ ), wydatki na rolnictwo indywidualne stanowiły 26\% (w latach 1950-1955 wydano na rolnictwo ogółem 5,3 mld zł, w tym indywidualne 1,4 mld). Oznacza to, że wydatki inwestycyjne na 1 hektar użytków rolnych w gospodarstwach nieuspołecznionych wynosiły 90 zł (według cen z 1961 r.), podczas gdy w gospodarstwach uspołecznionych $840 \mathrm{zł}$ (dane dla lat 1951-1955). W niektórych latach sytuacja był wręcz dramatyczna, biorąc pod uwagę, że np. w 1951 r. rolnictwo indywidualne dające ok. $90 \%$ produkcji rolnej partycypowało w całości inwestycji w gospodarce narodowej zaledwie w $1 \%(484 \mathrm{mln} z \mathrm{zl})^{15}$. Nota bene dyskryminacja gospodarstw chłopskich, mimo pewnej poprawy w następnych latach, utrzymała się do końca istnienia PRL.

W tym kontekście trudno się dziwić, że polskie rolnictwo cechowały zacofanie, niski poziom efektywności i duże zapotrzebowanie na siłę roboczą. W tym ostatnim przypadku, gdyby przyjąc konieczne standardy nasycenia siłą roboczą przy istniejącym wówczas wyposażeniu technicznym (biorąc pod uwagę niepodzielność siły roboczej, gospodarstwa do 10 ha potrzebowały 2 osób pracujących, powyżej 10 ha 3 osób), to praktycznie od początku nie było rezerwy siły roboczej, która mogłaby migrować ze wsi do miast. W 1950 r. w 2789,6 tys. gospodarstwach do 10 ha powinno bowiem pracować 5579,2 tys. osób, a w gospodarstwach powyżej 10 ha dalsze 1136,7 tys. osób. W sumie zatem 6715,9 tys. osób, podczas gdy w rzeczywistości pracowało 6349,4 tys. (2691,2 tys. ,gospodarujących” i 3658,2 tys. „pomagających członków rodzin") ${ }^{16}$.

Na początku lat 60 . wśród badaczy zajmujących się problematyką agrarną dość powszechne było przekonanie o wyczerpaniu się wolnej rezerwy siły roboczej na wsi, która mogłaby odpłynąć, nie wpływając negatywnie na efektywność rolnictwa. Nie tylko nie występowało już wówczas zjawisko ukrytego bezrobocia, lecz wręcz przeciwnie, w części gospodarstw i niektórych okresach odnotowywano deficyt siły roboczej. Przeprowadzona w 1962 r. ankieta wykazała, że rolnicy zazwyczaj stwier-

${ }_{13}$ S.W. Kłopot, Struktura agrarna indywidualnego rolnictwa w latach 1945-2010, Annales Universitatis Mariae Curie-Skłodowska. Sectio I 2011, vol. XXXVI, no. 2, s. 95-96.

${ }_{14}$ W. Herer, W. Sadowski, Migracje z rolnictwa. Efekty i koszty, PWE, Warszawa 1975, s. 52-54.

15 S. Ignar (red.), Polityka agrarna, PWN, Warszawa 1968, s. 86-90.

16 Rocznik Statystyczny 1958, s. 31, 140. 
dzali brak rąk do pracy w swoich gospodarstwach. Co gorsza, pojawiło się także zjawisko tzw. pustych chałup, tj. gospodarstw bez następców ${ }^{17}$. W połowie lat 60 . wskazywano także, że odpływ ludności ze wsi będzie wymagał bardzo znacznych kosztów substytucji odpływającej siły roboczej ${ }^{18}$. Wyczerpane zostały bowiem proste rezerwy związane np. $\mathrm{z}$ wydłużaniem czasu pracy osób zatrudnionych w rolnictwie. Nota bene w latach 30. czas pracy kobiet szacowano na 13 godzin na dobę, w latach 60. już 14 godzin, a pod koniec lat 70. „w zależności od obszaru gospodarstwa, rodzaju produkcji i stanu rodziny" $15-18$ godzin $^{19}$.

Warto w tym kontekście przypomnieć szacunki J. Nowickiego z połowy lat 80 . XX w. Biorąc pod uwagę ówczesne wyposażenie techniczne polskiego rolnictwa, strukturę upraw i znaczną ilość nieużytków rolnych, oszacował on niedobór siły roboczej na polskiej wsi na ponad 3,8 mln osób ${ }^{20}$. Wnioski te współbrzmią z opinią E. Kościk, która zwróciła uwagę, że odpływowi ludności wiejskiej w czasach PRL nie towarzyszyły procesy unowocześnienia wsi. W rzeczywistości zatem „migracje ze wsi nie oznaczały opuszczania jej przez nadmiar zbędnej siły roboczej, co byłoby przejawem modernizacji. Ubytek ludności wiejskiej widzieć powinno się w kategorii pozornej modernizacji" ${ }^{21}$.

Problemy wsi pogłębiał skład społeczno-demograficzny osób migrujących w latach 1945-1957. Dowodzą tego m.in. wyniki ankiety przeprowadzonej w 1957 r. przez Zakład Socjologii Wsi Instytutu Ekonomiki Rolnej. Wieś opuszczali bowiem przede wszystkim ludzie młodzi, stosunkowo dobrze wykształceni, o największym potencjale intelektualnym.

Skalę negatywnych zmian widać, jeżeli uwzględnimy konsekwencje migracji dla struktury wieku mieszkańców wsi. Już w 1955 r. odsetek osób w miastach w wieku największej produktywności zawodowej (20-49) wynosił 45,9\% (odsetek ten był taki sam dla mężczyzn i kobiet). W przypadku wsi odsetki te wynosiły odpowiednio: 40,4, 40,2 i 40,6\% ${ }^{22}$. W całej dekadzie 1950-1960 odsetek ludności zawodowo czynnej w rolnictwie indywidualnym w przypadku mężczyzn (wiek 14-49) zmniejszył się z 71,3 do $57,7 \%$, równolegle odsetek mężczyzn w wieku powyżej 50 lat wzrósł z 28,7 do 42,3\%. W przypadku kobiet (wiek 14-44 i 45 i więcej) odsetki te wynosiły odpowiednio: 64,7 i $53 \%$ oraz 35,3 i 47\% ${ }^{23}$. Odpływ ten oznaczał, że zmniejszająca się liczba osób czynnych zawodowo nie tylko musiała podołać obowiązkom prowadzenia gospodarstw, ale również wziąć na swoje barki utrzymanie osób niesamodzielnych (dzieci i osób w podeszłym wieku).

${ }^{17}$ M. Pohoski, wyd. cyt., s. 97-100.

${ }_{18}$ W. Herer, W. Sadowski, wyd. cyt., s. 52, 53.

19 A. Gawryszewski, Przestrzenna ruchliwość..., s. 42, 43.

20 J. Nowicki, Paradoks petnego zatrudnienia w Polsce, PWE, Warszawa 1989, s. 73, 74.

${ }^{21}$ E. Kościk, Migracje ze wsi do miast w latach PRL ze szczególnym uwzględnieniem Dolnego Śląska, [w:] Chumiński J. (red.), Modernizacja czy pozorna modernizacja. Społeczno-ekonomiczny bilans PRL 1944-1989, Wydawnictwo Gajt, Wrocław 2010, s. 314.

${ }^{22}$ Rocznik Statystyczny 1958, s. 22-24.

${ }^{23}$ M. Pohoski, wyd. cyt., s. 202. 
Nie zaskakuje także dominacja wśród migrantów mężczyzn nad kobietami. Jest to zresztą ogólna prawidłowość występująca w krajach socjalistycznych (np. w Związku Radzieckim w latach 1923-1938 migranci mężczyźni stanowili 60\%). Był to oczywiście skutek rozbudowy przemysłu ciężkiego, w którym zatrudnienie znajdowali przede wszystkim mężczyźni. Warto dodać, że na początku lat 60. niemal co trzeci z zatrudnionych w nierolniczych działach gospodarki w Polsce pochodził ze wsi ${ }^{24}$.

Długofalowym negatywnym dla wsi skutkiem migracji było także opuszczanie jej przez osoby lepiej wykształcone. Dotyczyło to zarówno kobiet, jak i mężczyzn oraz osób młodszych (przed 30. rokiem życia), jak i starszych powyżej 31 lat. Różnice były bardzo znaczne. Dość powiedzieć, że w latach 1945-1957 wśród mężczyzn do 30. roku życia wśród opuszczających wieś było 51,6\% osób o wykształceniu niepełnym i pełnym podstawowym, a wśród pozostających na wsi odsetek ten wynosił 79,3\%. W przypadku kobiet odsetki te wynosiły odpowiednio: 55,6 i 81,5\%. Badania w krajach zachodnich wskazują także, że osoby migrujące cechuje wyższy poziom inteligencji, są one zdolniejsze i bardziej aktywne niż pozostające na wsi ${ }^{25}$. W efekcie poziom wykształcenia ludności wiejskiej pod koniec PRL był bardzo niski. W 1978 r. spośród ponad 5,7 mln czynnych zawodowo w rolnictwie aż 24\% nie miało wykształcenia podstawowego, a 54\% zakończyło edukację na poziomie podstawowym ${ }^{26}$.

Nie ulega przy tym wątpliwości, że głównym powodem migracji było niedoinwestowanie polskiej wsi. Zapaść cywilizacyjna „wypychała” młodych ludzi, mimo że szansa na rzeczywisty awans materialny w miastach była niewielka. Skalę zaniedbań ilustruje wyposażenie gospodarstw w infrastrukturę techniczną. Dość powiedzieć, że w 1970 r. zaledwie 12,1\% mieszkań na wsi posiadało wodociąg, 5,5\% ustęp, 5,8\% łazienkę, 0,9\% gaz sieciowy i 4,5\% centralne ogrzewanie. Nieco lepiej sytuacja wyglądała w 1980 r., choć i tak dysproporcje w porównaniu do mieszkań w miastach były bardzo znaczne ${ }^{27}$. Niewiele lepiej wyglądało zaspokojenie potrzeb mieszkańców wsi na usługi społeczne. Trudno się jednak temu dziwić, biorąc pod uwagę, że na wsi pod koniec lat 70. pracowało 5\% lekarzy, 14\% stomatologów, 5,5\% pielęgniarek, $8 \%$ położnych, zaledwie $20 \%$ dzieci miało szanse na miejsce w przedszkolu itd. ${ }^{28}$ Nie można także pominąć tego, że masowe migracje ludności wiejskiej do miast spowodowały pogorszenie warunków życia ich mieszkańców. Wystąpiło bowiem zjawisko tzw. konsumpcji pozornej. Nakłady na infrastrukturę nie pokrywały bowiem rosnącego zapotrzebowania na te usługi związanego z rosnącą liczbą mieszkańców miast ${ }^{29}$.

${ }^{24}$ Tamże, s. 78, 167.

25 Tamże, s. 106, 126.

${ }^{26}$ Ludność wiejska zwiąana z rolnictwem indywidualnym. Badania metoda reprezentacyjna. Stan w dniu 8 grudnia 1982 r., GUS, Warszawa 1983, s. 28, 29.

27 Rocznik Statystyczny 1987, GUS, Warszawa 1987, s. 443.

${ }^{28}$ A. Gawryszewski, Przestrzenna ruchliwość..., s. 43.

${ }^{29}$ W. Herer, W. Sadowski, wyd. cyt., s. 86-88. 


\section{Ekonomiczne skutki zatrudnienia ludności wiejskiej w przemyśle}

Paradoks polega na tym, że migracja „wartościowszych” mieszkańców wsi wcale nie oznaczała efektywnego ich ,zagospodarowania” w miastach. Nie będzie przesady w stwierdzeniu, że niekorzystne z punktu widzenia gospodarczego i społecznego ukryte bezrobocie na wsi zostało „przeniesione” do miast, gdzie jego makroekonomiczne skutki były zdecydowanie bardziej dolegliwe.

Zjawisko to dotyczyło zwłaszcza przemysłu. Skalę nadmiernego zatrudnienia ilustruje to, że gdyby przyjąć przedwojenną wydajność pracy, to bez większego uszczerbku dla wielkości produkcji można by w pierwszej dekadzie tzw. Polski Ludowej zrezygnować niemal z całego ówczesnego wzrostu zatrudnienia. Przypomnijmy, że w 1950 r. osiągnięto wielkość produkcji przedwojennej (w nowych granicach), tyle tylko, że przy zatrudnieniu o ponad 600 tys. przekraczającym ówczesną liczbę pracowników. Symptomatyczne są wyniki badań z 1953 r. Zakładu Nauk Ekonomicznych PAN dotyczące szacunku rezerw wzrostu wydajności pracy w przemyśle wielkim i średnim (bez górnictwa). Badaniami objęto zakłady zatrudniające 309 tys. robotników i wytwarzające ok. 20\% produkcji globalnej. Wynikało z nich, że rezerwa zatrudnienia w całym przemyśle wynosiła, gdyby ujednolić poziom wydajności do najlepszych zakładów w branży, aż 615 tys. osób, czyli ponad 80\% wzrostu zatrudnienia w przemyśle, jakie nastąpiło między 1949 a 1953 r. Nawet gdyby uwzględnić przeciętny poziom wydajności w poszczególnych gałęziach, to rezerwa zatrudnienia wynosiła 400 tys. osób. W świetle tych danych nie dziwi konkluzja o „wielkim marnotrawstwie siły roboczej”, „wysokim poziomie kosztów własnych w dużej części przemysłu” i „możliwości wyswobodzenia dużej części siły roboczej i obniżenia kosztów własnych na skutek rekonstrukcji technicznej zakładów przestarzałych i usprawnienia w nich organizacji pracy”. Postulowano w związku z tym: „,[w] tych warunkach tolerowanie stanu, w którym znaczna część siły roboczej przemysłu, posiadająca nawyki i kwalifikacje produkcyjne, wykorzystana jest w sposób nieracjonalny, niedostateczny nie może trwać dłużej”30.

Zjawisko, by użyć tu określenia J. Kornaia, „bezrobocia w miejscu pracy”, było jednym z głównych źródeł słabości gospodarki socjalistycznej do końca istnienia PRL. Nie tylko bowiem prowadzi ono do „rozluźnienia dyscypliny pracy, pogorszenia jej jakości, zmniejszenia pracowitości robotników", zwiększonej fluktuacji kadr i skutecznie blokuje możliwość poprawy sytuacji materialnej pracowników, ale, co gorsza, osoby klasyfikowane jako „nadmiernie zatrudnione” mają zerową marginalną wydajność pracy. To ostatnie zjawisko oznacza, że praca tych ludzi w istocie nie

${ }^{30}$ Według innych szacunków w całej gospodarce narodowej liczba zatrudnionych w planie sześcioletnim wzrosła o 2232 tys., z tego 500 tys., czyli prawie $25 \%$, było to zatrudnienie zbędne. AAN, PKPG, sygn. 330, Szacunek rezerw wzrostu wydajności pracy w przemyśle wielkim i średnim (1953 r.), s. 17-27; A. Karpiński, Zagadnienia socjalistycznej industrializacji Polski, Polskie Wydawnictwo Gospodarcze, Warszawa 1958, s. 63. 
ma żadnego wpływu na wielkość dochodu narodowego ${ }^{31}$. W tym kontekście warto przypomnieć badania J. Nowickiego, który dla 1985 r. oszacował, że co drugiego zatrudnionego w różnych działach gospodarki narodowej w Polsce można było zakwalifikować do kategorii „ukrytego bezrobocia” (6226 tys. z 12452 tys.), a nadmierne zatrudnienie w przemyśle szacuje się zazwyczaj na ok. 25-30\% pracujących (np. według ustaleń P. Glikmana w $1980 \mathrm{r}$. w polskiej gospodarce narodowej stopa ukrytego bezrobocia wynosiła 26,7\%, a w przemyśle 29,7\%, w 1990 r. zaś szacowane zbędne zatrudnienie miało wynosić aż $5 \mathrm{mln}$ osób, tj. 41\% zatrudnionych poza rolnictwem) ${ }^{32}$.

Warto przy tym podkreślić, że zwłaszcza w pierwszej dekadzie po wojnie nadmierne zatrudnienie $\mathrm{w}$ przemyśle nie wynikało $\mathrm{z}$ potrzeb społecznych i gospodarczych. Sytuacja na rynku pracy świadczy, że bezrobocie nie było wówczas istotnym problemem (oscylowało w skali całego kraju na poziomie naturalnej stopy bezrobocia), choć z pewnością było dotkliwe w niektórych regionach Polski czy dla pewnych grup pracowników ${ }^{33}$.

Do pewnego stopnia ekonomiczna nieefektywność migracji ludności wiejskiej do miast wynikała także z jej cech społeczno-demograficznych. Zjawisko to zilustrujemy na przykładzie pracowników przemysłu. Dysponujemy bowiem danymi dla pracowników 4 zakładów ( 2 w Krakowie i 2 we Wrocławiu). Informacje te uzyskaliśmy z teczek personalnych przechowywanych w archiwach zakładowych. W sumie dysponujemy informacjami o 17183 pracownikach fizycznych i umysłowych, w tym 8404 osobach, które w sierpniu 1939 r. mieszkały na wsi i po wojnie migrowały do miast. W sumie baza danych liczy ok. 500 tys. rekordów i dzięki korelacji różnych cech może stanowić podstawę wnioskowania o cechach biospołecznych pracowników pochodzących z różnych środowisk.

Najistotniejszym czynnikiem, z punktu widzenia oceny przydatności pracowników do pracy w przemyśle, jest poziom wykształcenia. Znaczenie edukacji należy analizować na dwóch płaszczyznach. Po pierwsze, jest ono kluczowym wyznaczni-

31 J. Kornai, Niedobór w gospodarce, PWE, Warszawa 1985, s. 346, 347; A. Karpiński, Zarys rozwoju gospodarczego Polski Ludowej, Książka i Wiedza, Warszawa 1980, s. 129-132; M. Góra, M. Rutkowski, wyd. cyt., s. 421.

${ }^{32}$ Według szacunków P. Glikmana taka byłaby liczba bezrobotnych, gdyby „gospodarka polska $\mathrm{z}$ administrowanej centralnie przekształciła się od razu w gospodarkę rynkową typu kapitalistycznego". P. Glikman, Przekształcenia strukturalne potencjału produkcyjnego w warunkach transformacji gospodarki polskiej, Z Prac Zakładu Badań Statystyczno-Ekonomicznych GUS 1993, z. 210, s. 78; tenże, Systemowe determinanty $i$ kierunki restrukturyzacji majątku trwałego w przemyśle, Poltext, Warszawa 1993, s. 27; J. Nowicki, wyd. cyt., s. 50, 51, 70; M. Góra, M. Rutkowski, wyd. cyt., s. 424, 425.

${ }^{33} \mathrm{~W}$ tym kontekście rację ma z pewnością M. Zaremba, przypisując bezrobociu duże znaczenie w kształtowaniu nastrojów społeczeństwa polskiego w pierwszych latach po wojnie. Choć można oczywiście dyskutować nad znaczeniem tego czynnika, zwłaszcza jeżeli uwzględnimy jego natężenie w skali makroekonomicznej i doświadczeń przedwojennych, kiedy to bezrobocie (jawne i ukryte) było rzeczywiście bardzo poważnym problemem społecznym. M. Zaremba, Wielka Trwoga Polska 1944-1947. Ludowa reakcja na kryzys, Znak, Kraków 2012, s. 233-246. 
kiem kapitału ludzkiego, czynnika, który obecnie dość powszechnie jest uznawany za podstawowy warunek szybkiego rozwoju gospodarczego. Istnieje prosta zależność potwierdzana w licznych badaniach - im wyższe wykształcenie pracowników, tym większy wzrost gospodarczy ${ }^{34}$. Po drugie, wykształcenie ma bezpośredni wpływ na postawy ludzi, zwłaszcza na poziom autorytaryzmu. Sformułowana w $1955 \mathrm{r}$. znana teza S.M. Lipseta o autorytarnym charakterze klasy robotniczej opierała się na przekonaniu, że istnieje ścisły związek między niskim poziomem wykształcenia a wysokim natężeniem postaw autorytarnych. Mimo kontrowersji, jakie wywołała opinia Lipseta, właściwie nikt obecnie nie kwestionuje, że ograniczona perspektywa poznawcza jednostki skutkuje skłonnością do autorytarnej uległości i konfor$\mathrm{mizmu}^{35}$.

W tym kontekście trzeba podkreślić, że poziom wykształcenia pracowników ze wsi był zdecydowanie gorszy niż pracowników wywodzących się z innych środowisk. Na potrzeby naszej analizy oprócz osób mieszkających w sierpniu 1939 r. na wsi i migrujących po wojnie do miast, wyodrębniliśmy mieszkańców miast małych do 50 tys. mieszkańców i dużych powyżej 50 tys. mieszkańców (tab. 1). Skale różnic ilustruje wskaźnik wykształcenia.

Tylko w przypadku byłych mieszkańców wsi był on wyraźnie poniżej wykształcenia podstawowego 6,55 (kobiety 6,41 i mężczyźni 6,7). Dla mieszkańców miast małych wynosił odpowiednio: 7,32, 6,96 i 7,68, a miast dużych - 7,73, 7,4 i 8,05. Oznacza to, że w przypadku byłych mieszkańców wsi aż 40,8\% pracowników miało wykształcenie poniżej podstawowego, a dalsze 32,4\% legitymowało się ukończoną szkołą podstawową. W sumie zatem $73,2 \%$ osób miało minimalny poziom wykształcenia (kobiety 78,5\%, mężczyźni $67,8 \%$ ). W przypadku mieszkańców miast odsetki te są o kilkanaście procent niższe (miasta małe $62,5 \%$, kobiety $72 \%$, mężczyźni 52,6\%; miasta duże odpowiednio: 53,2, 59,8 i 46,8\%).

Dane te są o tyle wymowne, że niski poziom wykształcenia miał zasadniczy wpływ na produktywność pracowników ${ }^{36}$. Dotyczy to zwłaszcza ich zdolności adaptacyjnych. Osoby o minimalnym poziomie wykształcenia zdolne są bowiem tylko do wykonywania pracy prostej i powtarzanej. Możliwości zwiększenia wydajności

${ }^{34}$ Przez kapitał ludzki należy rozumieć „zasób wiedzy, umiejętności, zdolności, kwalifikacji, postaw, motywacji oraz zdrowia, o określonej wartości, będący źródłem przyszłych zarobków czy satysfakcji, przy czym jest odnawialnym i stale powiększanym potencjałem ludzkim". Warto podkreślić, że za badania nad kapitałem ludzkim Nagrodami Nobla wyróżniono w 1979 r. T. Schultza i w 1992 r. G.S. Beckera. G. Łukasiewicz, Kapitat ludzki organizacji. Pomiar i sprawozdawczość, Wydawnictwo Naukowe PWN, Warszawa 2009, s. 19.

35 S.M. Lipset, Homo politicus. Spoleczne podstawy polityki, Wydawnictwo Naukowe PWN, Warszawa 1995, s. 102.

${ }^{36}$ Przez produktywność można rozumieć w wąskim ujęciu ilość dóbr wytworzonych przez pracownika w jednostce czasu; albo w ujęciu szerszym ,tendencje do [...] wytwarzania, powiększania puli dóbr materialnych czy idealnych, czerpania z siebie, używania swoich sił i środków”. J. Koralewicz, M. Ziółkowski, Mentalność Polaków. Sposoby myślenia o polityce, gospodarce i życiu społecznym 1988-2000, Scholar, Warszawa 2003, s. 32. 
ograniczane są przez czynniki biopsychiczne. Dopiero przekroczenie wykształcenia podstawowego otwiera możliwości do zwiększenia produktywności, zwłaszcza przez szybsze i efektywniejsze adaptowanie się do zmian technologicznych, organizacyjnych czy do stosowania nowych narzędzi w procesie produkcji ${ }^{37}$. Warto przytoczyć wyniki badań prowadzonych w Polsce w latach 60. Dodatkowy rok nauki powodował wzrost wydajności pracownika o ok. 2\%, a amortyzacja nakładów na wykształcenie polskich pracowników przemysłu następowała już po ok. 5 latach. $Z$ badań tych wynika także, że w przemyśle metalowym robotnicy o wykształceniu niepełnym podstawowym zatrudnieni do 3 lat wykonywali przeciętnie zaledwie $98,6 \%$ norm produkcyjnych, podczas gdy robotnicy legitymujący się wykształceniem zawodowym $105 \%$, w przypadku zaś przemysłu budowlanego, ceramicznego, chemicznego i górnictwa odpowiednio 99 i 107\%. Znamienne, że dysproporcje te rosną, jeżeli uwzględnimy staż pracy robotników. Wśród pracujących bowiem powyżej 10 lat w przemyśle metalowym robotnicy o wykształceniu poniżej podstawowego wykonywali przeciętnie normy w $105 \%$, a robotnicy o wykształceniu zawodowym $116,8 \%$. W innych gałęziach stopień wykonania norm wynosił odpowiednio 104,9 i 117,7\% (niewiele lepsza niż robotników o wykształceniu niepełnym podstawowym była wydajność robotników, którzy ukończyli szkołę podstawową) ${ }^{38}$. W tym kontekście nie ulega wątpliwości, że niskie wykształcenie pracowników ze wsi, których odsetek na początku lat 60 . był bardzo znaczny (według obliczeń S. Widerszpila $55,4 \%$ polskich robotników wychowywało się do 14 . roku życia na wsi), miało istotny wpływ na niską efektywność polskiego przemysłu ${ }^{39}$.

Analizę poziomu wykształcenia pracowników przemysłu uzupełnimy o dane dotyczące ich wcześniejszego doświadczenia zawodowego (tab. 2). Te dwa czynniki są bowiem podstawą określenia kwalifikacji zawodowych ${ }^{40}$.

$\mathrm{Z}$ naszego punktu widzenia najważniejsze jest przygotowanie fachowe pracowników nabyte przed wojną. Jeżeli bowiem nie mieli oni nawet wykształcenia zawo-

37 J. Orczyk, Ekonomiczna interpretacja procesu kształcenia (propozycja modelowa), Kwartalnik Pedagogiczny 1985, nr 2, s. 36.

${ }^{38}$ L. Leja, Produkcyjne i ekonomiczne efekty wyksztatcenia pracowników zatrudnionych w przemyśle, [w:] Kluczyński J. (red.), Ekonomiczne i społeczne aspekty kształcenia, Książka i Wiedza, Warszawa 1968, s. 70-81; tenże, Ksztatcenie kadr zawodowych w konińskim i tarnobrzeskim rejonie przemysłowym, Wydawnictwo Poznańskie, Poznań 1964; A. Wieczorek-Szymańska, Koncepcje kapitatu ludzkiego w teorii ekonomii - przegląd wybranych podejść, Studia i Prace Wydziału Nauk Ekonomicznych i Zarządzania 2010, nr 17, s. 162.

39 S. Widerszpil, Skład polskiej klasy robotniczej. Tendencje zmian $w$ okresie industrializacji socjalistycznej, PWN, Warszawa 1965, s. 102, 103, 220.

40 Trzeba podkreślić, że termin „kwalifikacje zawodowe” jest wieloznaczny. Kwalifikacje w wąskim znaczeniu obejmują wiedzę teoretyczną i doświadczenie praktyczne. W szerszym ujęciu obejmują one także cechy psychofizyczne (takie jak wiek, stan zdrowia itd.) i psychospołeczne jednostki (np. umiejętność współpracy, kierowania ludźmi). R. Stec, Kwalifikacje zawodowe załogi huty aluminium, [w:] Dobrowolski K. Stojak A. (red.), Studia nad załoga huty aluminium w Skawinie, Wrocław 1969, s. $133,134$. 
Tabela 2. Przedwojenne doświadczenie zawodowe pracowników przemysłu według środowiska zamieszkania 31 sierpnia $1939 \mathrm{r}$.

\begin{tabular}{|c|c|c|c|c|c|c|c|c|}
\hline \multirow[b]{2}{*}{$\begin{array}{l}\text { Doświadczenie } \\
\text { w pracy }\end{array}$} & \multicolumn{8}{|c|}{ Pracownicy przemysłu w latach 1945-1956 zamieszkali 31 sierpnia 1939 r.: } \\
\hline & na wsi & $\%$ & $\begin{array}{l}\text { w miastach } \\
\text { do } 50 \text { tys. }\end{array}$ & $\%$ & $\begin{array}{c}\text { w miastach } \\
\text { powyżej } \\
50 \text { tys. }\end{array}$ & $\%$ & ogółem & $\%$ \\
\hline \multicolumn{9}{|c|}{ Zatrudnieni w przemyśle w latach 1945-1956 } \\
\hline Ogółem & 8404 & & 2904 & & 5875 & & 17183 & \\
\hline $\begin{array}{l}\text { w tym: kobiety } \\
\text { mężczyźni }\end{array}$ & $\begin{array}{l}4222 \\
4182\end{array}$ & $\begin{array}{l}50,24 \\
49,76\end{array}$ & $\begin{array}{l}1471 \\
1433\end{array}$ & $\begin{array}{l}50,65 \\
49,35\end{array}$ & $\begin{array}{l}2884 \\
2991\end{array}$ & $\begin{array}{l}49,09 \\
50,91\end{array}$ & $\begin{array}{l}8677,89 \\
8705,11\end{array}$ & $\begin{array}{l}50,50 \\
50,66\end{array}$ \\
\hline \multicolumn{9}{|c|}{ Zatrudnieni z przedwojennym doświadczeniem } \\
\hline Budownictwo & 23 & 0,27 & 13 & 0,45 & 58 & 0,99 & 94,7213 & 0,55 \\
\hline Fabryka & 201 & 2,39 & 249 & 8,57 & 857 & 14,59 & 1317,97 & 7,67 \\
\hline Handel & 29 & 0,35 & 36 & 1,24 & 127 & 2,16 & 193,585 & 1,13 \\
\hline Rzemiosło & 283 & 3,37 & 227 & 7,82 & 540 & 9,19 & 1061,18 & 6,18 \\
\hline Spółdzielczość & 7 & 0,08 & 7 & 0,24 & 7 & 0,12 & 21,3243 & 0,12 \\
\hline Urząd & 34 & 0,40 & 44 & 1,52 & 197 & 3,35 & 276,92 & 1,61 \\
\hline Usługi & 49 & 0,58 & 60 & 2,07 & 213 & 3,63 & 324,649 & 1,89 \\
\hline Razem & 626 & 7,45 & 636 & 21,90 & 1999 & 34,03 & 3290,35 & 19,15 \\
\hline $\begin{array}{l}\text { w tym: kobiety } \\
\text { mężczyźni }\end{array}$ & $\begin{array}{l}177 \\
449\end{array}$ & $\begin{array}{r}4,19 \\
10,74\end{array}$ & $\begin{array}{l}205 \\
431\end{array}$ & $\begin{array}{l}13,94 \\
30,08\end{array}$ & $\begin{array}{r}783 \\
1216\end{array}$ & $\begin{array}{l}27,15 \\
40,66\end{array}$ & $\begin{array}{l}1183,13 \\
2136,81\end{array}$ & $\begin{array}{l}13,63 \\
24,55\end{array}$ \\
\hline
\end{tabular}

Źródło: jak w tab. 1.

dowego odpowiadającego ściśle branży, w jakiej znaleźli zatrudnienie po wojnie, to jednak dzięki znajomości specyfiki np. systemu fabrycznego łatwiej dostosowywali się do wymagań stawianych w nowych miejscach pracy. W tym kontekście trzeba podkreślić, że przedwojenne doświadczenie zawodowe migrantów ze wsi było bardzo niewielkie. Zaledwie 7,5\% pracowało przed 1939 r. (kobiety - 4,2\%, mężczyźni - 10,7\%), z tego doświadczenie w pracy fabrycznej miało 2,4\% pracowników. Relatywnie najwięcej zatrudnionych było w rzemiośle (3,4\%), niewielki odsetek pracował natomiast w budownictwie, usługach, handlu, spółdzielczości i urzędach - w sumie $1,7 \%$. W przypadku miast małych ogólny odsetek pracujących wynosił $21,9 \%$ (kobiety 13,9\%, mężczyźni 30,1\%), a miast dużych odpowiednio: 34, 27,2 i 40,7\%.

Ostatnia kwestia, którą poddamy analizie, to sytuacja rodzinna pracowników (tab. 3). Stan cywilny jest bowiem ważnym wskaźnikiem osiągniętego poziomu stabilizacji życiowej. Osoby, które zawarły związek małżeński, zwłaszcza z chwilą pojawienia się dzieci, wykazują wyraźnie mniejszą skłonność do zmiany miejsca pracy. Ale nie tylko, posiadanie rodziny wpływało w sposób pośredni na warunki materialne zatrudnionych. Osoby bezżenne nawet przy niskich płacach znajdowały się $\mathrm{w}$ stosunkowo nie najgorszej sytuacji w porównaniu z mającymi na utrzymaniu kilka osób. 
Tabela 3. Sytuacja rodzinna pracowników przemysłu według środowiska zamieszkania 31 sierpnia 1939 r.

\begin{tabular}{|c|c|c|c|c|c|c|}
\hline \multirow{2}{*}{\multicolumn{2}{|c|}{\begin{tabular}{|c|} 
\\
Środowisko zamieszkania \\
31 sierpnia $1939 \mathrm{r}$.
\end{tabular}}} & \multicolumn{5}{|c|}{ Stan cywilny } \\
\hline & & \multirow{2}{*}{\begin{tabular}{|c|}
$\begin{array}{c}\text { osoby } \\
\text { żonate } \\
\text { i zamężne }\end{array}$ \\
1048 \\
\end{tabular}} & \multirow{2}{*}{\begin{tabular}{|r}
$\begin{array}{c}\text { panny } \\
\text { i kawalerowie }\end{array}$ \\
3029 \\
\end{tabular}} & \multirow{2}{*}{$\begin{array}{r}\begin{array}{c}\text { osoby } \\
\text { owdowiałe }\end{array} \\
134 \\
\end{array}$} & \multirow{2}{*}{$\begin{array}{r}\begin{array}{c}\text { osoby } \\
\text { rozwiedzione }\end{array} \\
11\end{array}$} & \multirow{2}{*}{$\begin{array}{r}\text { ogółem } \\
422 \\
\end{array}$} \\
\hline \multirow[t]{6}{*}{ Wieś } & kobiety & & & & & \\
\hline & $\%$ & 24,82 & 71,74 & 3,17 & 0,26 & 100,00 \\
\hline & mężczyźni & 1390 & 2775 & 16 & 1 & 4182 \\
\hline & $\%$ & 33,24 & 66,36 & 0,38 & 0,02 & 100,00 \\
\hline & razem & 2438 & 5804 & 150 & 12 & 8404 \\
\hline & $\%$ & 29,01 & 69,06 & 1,78 & 0,14 & 100,00 \\
\hline \multirow{6}{*}{$\begin{array}{l}\text { Miasta } \\
\text { do } 50 \text { tys. }\end{array}$} & kobiety & 479 & 862 & 119 & 11 & 1471 \\
\hline & $\%$ & 32,56 & 58,60 & 8,09 & 0,75 & 100,00 \\
\hline & mężczyźni & 654 & 761 & 14 & 4 & 1433 \\
\hline & $\%$ & 45,64 & 53,11 & 0,98 & 0,28 & 100,00 \\
\hline & razem & 1133 & 1623 & 133 & 15 & 2904 \\
\hline & $\%$ & 39,02 & 55,89 & 4,58 & 0,52 & 100,00 \\
\hline \multirow{6}{*}{$\begin{array}{l}\text { Miasta } \\
\text { powyżej } \\
50 \text { tys. }\end{array}$} & kobiety & 933 & 1635 & 289 & 27 & 2884 \\
\hline & $\%$ & 32,35 & 56,69 & 10,02 & 0,94 & 100,00 \\
\hline & mężczyźni & 1525 & 1422 & 27 & 17 & 2991 \\
\hline & $\%$ & 50,99 & 47,54 & 0,90 & 0,57 & 100,00 \\
\hline & razem & 2458 & 3057 & 316 & 44 & 5875 \\
\hline & $\%$ & 41,84 & 52,03 & 5,38 & 0,75 & 100,00 \\
\hline \multirow[t]{6}{*}{ Ogółem } & kobiety & 2460 & 5526 & 542 & 49 & 8577 \\
\hline & $\%$ & 28,68 & 64,43 & 6,32 & 0,57 & 100,00 \\
\hline & mężczyźni & 3569 & 4958 & 57 & 22 & 8606 \\
\hline & $\%$ & 41,47 & 57,61 & 0,66 & 0,26 & 100,00 \\
\hline & razem & 6029 & 10484 & 599 & 71 & 17183 \\
\hline & $\%$ & 35,09 & 61,01 & 3,49 & 0,41 & 100,00 \\
\hline
\end{tabular}

Źródło: jak w tab. 1.

W tym kontekście istotne jest, że wśród byłych mieszkańców wsi odsetek osób bezżennych w momencie rozpoczęcia pracy wynosił aż 69,1\% (kobiety 71,7\%, mężczyźni $66,4 \%$ ). Wśród mieszkańców miast małych odsetki te wynosiły 55,9\% (kobiety 58,6\% i mężczyźni 53,1\%), miast dużych odpowiednio: 52, 56,7 i 47,5\%. Nieustabilizowana sytuacja rodzinna przekładała się na dużą płynność pracowników wywodzących się ze wsi: aż 65,7\% pracowało w badanych zakładach krócej niż rok (kobiety 63,4\%, mężczyźni 68\%). Gdyby zaś uwzględnić także pracujących do 3 lat, to odsetek ten w przypadku byłych mieszkańców wsi wzrasta do $80,9 \%$.

Różnice między różnymi grupami pracowników można zilustrować za pomocą wielowymiarowej analizy statystycznej z wykorzystaniem metody porządkowania liniowego, która pozwala zagregować i przedstawić w syntetycznej formie cechy społeczno-demograficzne pracowników (tab. 4). 


\begin{tabular}{|c|c|c|c|c|c|c|c|c|c|c|}
\hline \multirow{12}{*}{ 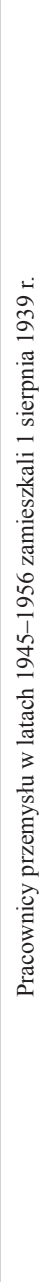 } & \multirow{3}{*}{$\begin{array}{l}\text { 胥 } \\
\text { : } \\
\text { : }\end{array}$} & 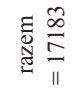 & $\begin{array}{l}\infty \\
\stackrel{-}{r}\end{array}$ & $\stackrel{n}{a}$ & $\vec{m}$ & $\stackrel{+}{\infty}$ & $\begin{array}{l}\text { qे } \\
\text { di }\end{array}$ & 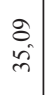 & $\vec{b}$ & $\begin{array}{l}\tilde{2} \\
\tilde{0}\end{array}$ \\
\hline & & 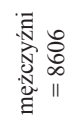 & $\stackrel{m}{\sim}$ & 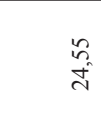 & $\stackrel{2}{m}$ & $\begin{array}{l}+ \\
\text { n. } \\
\infty\end{array}$ & 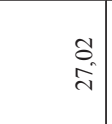 & $\begin{array}{l}\vec{f} \\
\vec{f}\end{array}$ & $\vec{\circ}$ & 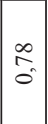 \\
\hline & & 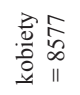 & $\begin{array}{l}\dot{D} \\
0_{0}^{\circ}\end{array}$ & $\begin{array}{l}\hat{b} \\
\stackrel{2}{7}\end{array}$ & $\vec{b}$ & $\begin{array}{l}\tilde{2} \\
\infty \\
\infty\end{array}$ & $\begin{array}{l}\stackrel{n}{a} \\
\dot{\sim}\end{array}$ & $\begin{array}{l}\infty \\
0 \\
0 \\
0 \\
\end{array}$ & $r$ & $\begin{array}{l}5 \\
0 \\
0\end{array}$ \\
\hline & \multirow{3}{*}{ 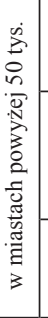 } & 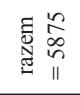 & $\stackrel{\Re}{\approx}$ & $\begin{array}{l}\tilde{O} \\
\dot{m}\end{array}$ & $\begin{array}{l}\stackrel{0}{*} \\
\rightarrow\end{array}$ & $\stackrel{?}{\stackrel{\leftrightarrow}{\circ}}$ & $\begin{array}{l}\stackrel{0}{0} \\
\stackrel{i}{ }\end{array}$ & $\begin{array}{l}\vec{D} \\
\vec{f} \\
\vec{f}\end{array}$ & $\stackrel{ }{\hat{\sigma}}$ & $\begin{array}{l}\bar{a} \\
\sigma\end{array}$ \\
\hline & & 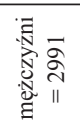 & $\begin{array}{l}2 \\
\infty^{\circ}\end{array}$ & $\begin{array}{l}: \\
\stackrel{0}{a}\end{array}$ & $\begin{array}{l}\approx \\
\stackrel{f}{f}\end{array}$ & $\begin{array}{l}\hat{n} \\
0 \\
0\end{array}$ & $\begin{array}{l}\hat{\infty} \\
\text { aे }\end{array}$ & $\begin{array}{l}\hat{\partial} \\
\dot{\hat{n}}\end{array}$ & $\stackrel{+}{=}$ & - \\
\hline & & 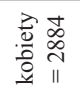 & $\stackrel{+}{\sim}$ & 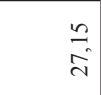 & 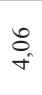 & $\begin{array}{l}\stackrel{1}{1} \\
\stackrel{\Omega}{0}\end{array}$ & $\begin{array}{l}\tilde{\lambda} \\
\hat{\imath}\end{array}$ & $\begin{array}{l}m \\
\tilde{m} \\
\tilde{m}\end{array}$ & $\begin{array}{l}\hat{0} \\
\infty\end{array}$ & $\begin{array}{l}\infty \\
\infty \\
0\end{array}$ \\
\hline & \multirow{3}{*}{ 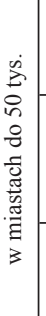 } & 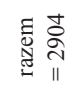 & $\begin{array}{l}\tilde{2} \\
\sim\end{array}$ & $\overrightarrow{\vec{N}}$ & $\stackrel{m}{m}$ & శ్ & $\begin{array}{l}\stackrel{m}{m} \\
\stackrel{\sim}{\sim}\end{array}$ & $\begin{array}{l}\tilde{\delta} \\
0 \\
\tilde{m}\end{array}$ & $\begin{array}{l}\infty \\
\stackrel{\infty}{\sim}\end{array}$ & $\begin{array}{l} \pm \\
\tilde{0}\end{array}$ \\
\hline & & 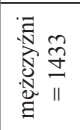 & $\mid \begin{array}{l}\infty \\
0 \\
r\end{array}$ & $\begin{array}{l}\infty \\
0 \\
0 \\
\dot{m}\end{array}$ & $\hat{m}$ & $\begin{array}{l}\infty \\
0 \\
\therefore\end{array}$ & $\begin{array}{c}\text { ते } \\
\text { iो }\end{array}$ & $\begin{array}{c}d \\
\dot{b} \\
\text { on }\end{array}$ & $\stackrel{2}{\stackrel{2}{r}}$ & $\begin{array}{c}\vec{\infty} \\
\infty \\
0\end{array}$ \\
\hline & & 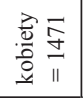 & \begin{tabular}{l}
$\circ$ \\
\multirow{2}{0}{}
\end{tabular} & $\begin{array}{l}\Delta \\
\stackrel{2}{~}\end{array}$ & $\overrightarrow{\hat{i}}$ & $\begin{array}{l}8 \\
\text { in }\end{array}$ & 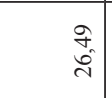 & 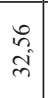 & $\underset{\infty}{\stackrel{f}{0}}$ & $\begin{array}{l}0 \\
0 \\
0\end{array}$ \\
\hline & \multirow{3}{*}{ 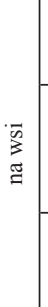 } & 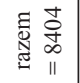 & 古 & 㲚 & $\stackrel{0}{\circ}$ & $\begin{array}{l}0 \\
0 \\
\sim\end{array}$ & $\begin{array}{l}\hat{\infty} \\
\hat{\lambda}\end{array}$ & $\begin{array}{l}\overrightarrow{0} \\
\vec{i}\end{array}$ & $\stackrel{\curvearrowright}{\stackrel{f}{+}}$ & $\begin{array}{l}0 \\
0\end{array}$ \\
\hline & & 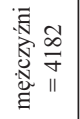 & $\hat{\sigma}^{\circ}$ & $\begin{array}{l}\stackrel{t}{0} \\
\stackrel{0}{\varrho}\end{array}$ & $\begin{array}{l}n \\
\tilde{n}\end{array}$ & $\frac{n}{n}$ & $\begin{array}{l}\tilde{n} \\
\tilde{d}\end{array}$ & $\begin{array}{l}\stackrel{+}{ } \\
\stackrel{m}{m}\end{array}$ & $\stackrel{\infty}{\infty}$ & $\begin{array}{l}0 \\
0 \\
0 \\
0\end{array}$ \\
\hline & & 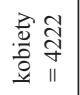 & $\begin{array}{l}F_{0} \\
\delta\end{array}$ & $\frac{\partial}{\vec{f}}$ & \begin{tabular}{|l}
$\hat{\sigma}$ \\
$\tilde{n}^{2}$
\end{tabular} & $\stackrel{2}{\curvearrowright}$ & $\begin{array}{l}\infty \\
m^{\infty} \\
\tilde{\lambda}^{2}\end{array}$ & $\begin{array}{l}\tilde{D} \\
\dot{d} \\
\dot{d}\end{array}$ & $\begin{array}{l}\hat{A} \\
\text { in }\end{array}$ & $\begin{array}{l}n \\
n \\
0\end{array}$ \\
\hline \multicolumn{3}{|c|}{ 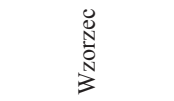 } & $\begin{array}{l}n \\
\infty \\
\infty\end{array}$ & $\begin{array}{l}0 \\
: \\
\stackrel{+}{+}\end{array}$ & 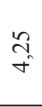 & $\begin{array}{l}n \\
0 \\
0\end{array}$ & $\begin{array}{l}\hat{\infty} \\
\hat{j}^{2}\end{array}$ & $\begin{array}{l}\hat{\sigma} \\
\hat{n}\end{array}$ & $\stackrel{\Xi}{=}$ & - \\
\hline \multicolumn{3}{|c|}{$\begin{array}{l}\overline{50} \\
3 \\
3\end{array}$} & สุ & สิ & $=$ & $=$ & $\Rightarrow$ & $=$ & $=$ & - \\
\hline \multicolumn{3}{|c|}{ 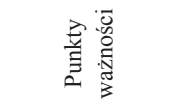 } & $N$ & $N$ & - & - & - & - & - & $a$ \\
\hline \multicolumn{3}{|c|}{$\begin{array}{l}\overrightarrow{0} \\
\text { d } \\
\text { Un }\end{array}$} & 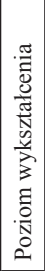 & 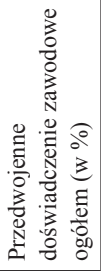 & 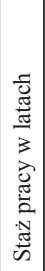 & 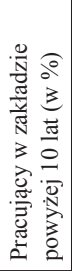 & 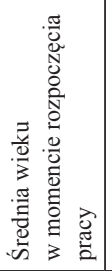 & 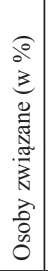 & 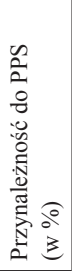 & 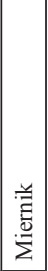 \\
\hline
\end{tabular}


W analizie uwzględniliśmy 7 cech (oprócz poziomu wykształcenia, przedwojennego doświadczenia zawodowego i sytuacji rodzinnej, także staż pracy w latach, odsetek długotrwale zatrudnionych powyżej 10 lat w zakładzie, wiek w momencie rozpoczęcia pracy i należących do PPS), które traktujemy jako świadczące o potencjalnej wartości środowiska pracowniczego. Oczywiście ustalone mierniki należy traktować z dużą ostrożnością, trudno bowiem precyzyjnie wyrazić różnice jakościowe za pomocą mierników ilościowych. Warto jednak podkreślić, że uzyskane dane dla ponad 17 tys. osób potwierdzają gorsze przygotowanie pracowników pochodzących ze wsi niż wywodzących się z miast. Dość powiedzieć, że miernik ilustrujący potencjalną wartość pracowników, którzy w sierpniu 1939 r. mieszkali na wsi, wynosił 0,6 (kobiety 0,57, mężczyźni 0,62), w przypadku migrujących z miast poniżej 50 tys. $0,74(0,66$ i 0,81$)$ i mieszkających w sierpniu 1939 r. w miastach powyżej 50 tys. 0,91 ( 0,83 i 1). Proporcje te świadczą o jakościowej różnicy zwłaszcza między migrantami ze wsi i robotnikami wywodzącymi się z miast dużych. W przypadku tych ostatnich pracowników analizowane parametry zawsze były wyraźnie wyższe niż w przypadku pracowników pochodzących ze wsi, a jeżeli uwzględnimy mężczyzn, to wynosił on 1, co oznacza, że pracownicy ci osiągnęli najwyższe wartości przy wszystkich badanych cechach.

\section{Wnioski}

W kontekście przeprowadzonej analizy uzasadnione wydają się trzy tezy.

Po pierwsze, kształt przeprowadzonej we wrześniu 1944 r. reformy rolnej miał istotny wpływ na długofalowe zacofanie polskiej wsi. Petryfikacja rozdrobnienia agrarnego oznaczała brak prywatnych środków inwestycyjnych, które mogłyby służyć unowocześnieniu gospodarstw. Problem ten dodatkowo pogłębiała polityka państwa wyraźnie upośledzająca rolnictwo w stosunku do innych działów gospodarki narodowej. Oznaczało to, że bardzo szybko wyczerpały się możliwości migracji ludności wiejskiej przy zerowych kosztach substytucji. Odpływ siły roboczej wymagał bowiem wysokich nakładów, których nie było. W konsekwencji polska wieś pozostała zacofana i nieefektywna i dość szybko zaczęła odczuwać brak rąk do pracy.

Po drugie, migrująca do miast ludność nie była w sposób racjonalny wykorzystywana. Większość znajdowała zatrudnienie w przemyśle, zasilając szeregi pracowników, których można zakwalifikować do kategorii „ukrytego bezrobocia”, ze wszystkimi tego negatywnymi makroekonomicznymi konsekwencjami. Do pewnego stopnia był to efekt ich cech społeczno-demograficznych. Odbiegali oni bowiem in minus od pracowników wywodzących się z innych środowisk.

Po trzecie wreszcie, głównym powodem migracji ludności wiejskiej było zacofanie cywilizacyjne wsi. $Z$ drugiej jednak strony masowy napływ tych ludzi do miast miał wpływ na pogorszenie warunków egzystencji ich mieszkańców. Inwestycje w rozwój infrastruktury miejskiej nie nadążały bowiem za rosnącą liczbą ludności. 


\section{Literatura}

Chumiński J., Koncepcje rozwiązania problemów ludnościowych i przebieg zasiedlenia Wroctawia w latach 1945-1949, Przegląd Zachodniopomorski 1995, R. X (XXXIX), z. 1.

Gawryszewski A., Ludność Polski w XX wieku, PAN, Warszawa 2005.

Gawryszewski A., Przestrzenna ruchliwość ludności Polski 1952-1985, Ossolineum, Wrocław 1989.

Glikman P., Przeksztatcenia strukturalne potencjału produkcyjnego w warunkach transformacji gospodarki polskiej, Z Prac Zakładu Badań Statystyczno-Ekonomicznych GUS 1993, z. 210.

Glikman P., Systemowe determinanty i kierunki restrukturyzacji majątku trwałego w przemyśle, Poltext, Warszawa 1993.

Góra M., Rutkowski M., Popyt na pracę oraz bezrobocie ukryte w Polsce w latach 1980-ych, Ekonomista 1990, nr 2-3.

Herer W., Sadowski W., Migracje z rolnictwa. Efekty i koszty, PWE, Warszawa 1975.

Historia Polski w liczbach. Państwo i społeczeństwo, T. I, GUS, Warszawa 2003.

Ignar S. (red.), Polityka agrarna, PWN, Warszawa 1968.

Jakubowski W., Chtopi polscy 1944-1948. Perspektywa psychohistoryczna, Instytut Nauk Politycznych Uniwersytetu Warszawskiego i Wyższa Szkoła Humanistyczna w Pułtusku, Pułtusk-Warszawa 2000.

Jarosz-Nojszewska A., Józef Maria Poniatowski i „, Gospodarka Narodowa”, Gospodarka Narodowa 2011, R. LXXX/XXI nr 5-6 (237-238).

Karpiński A., Zagadnienia socjalistycznej industrializacji Polski, Polskie Wydawnictwo Gospodarcze, Warszawa 1958.

Karpiński A., Zarys rozwoju gospodarczego Polski Ludowej, Książka i Wiedza, Warszawa 1980.

Kłopot S.W., Struktura agrarna indywidualnego rolnictwa w latach 1945-2010, „Annales Universitatis Mariae Curie-Skłodowska. Sectio I" 2011, vol. XXXVI, no. 2.

Koralewicz J., Ziółkowski M., Mentalność Polaków. Sposoby myślenia o polityce, gospodarce i życiu społecznym 1988-2000, Scholar, Warszawa 2003.

Kornai J., Niedobór w gospodarce, PWE, Warszawa 1985.

Kościk E., Migracje ze wsi do miast w latach PRL ze szczególnym uwzględnieniem Dolnego Ślaska, [w:] Chumiński J. (red.), Modernizacja czy pozorna modernizacja. Społeczno-ekonomiczny bilans PRL 1944-1989, Wydawnictwo Gajt, Wrocław 2010.

Latuch K.J., Straty demograficzne Polski w latach 1939-1945 (z prac nad weryfikacja oficjalnych szacunków), Polska 1939-1945. Straty osobowe i ofiary represji pod dwiema okupacjami, IPN, Warszawa 2009.

Leja L., Ksztatcenie kadr zawodowych w konińskim i tarnobrzeskim rejonie przemysłowym, Wydawnictwo Poznańskie, Poznań 1964.

Leja L., Produkcyjne i ekonomiczne efekty wykształcenia pracowników zatrudnionych w przemyśle, [w:] Kluczyński J. (red.), Ekonomiczne i społeczne aspekty ksztatcenia, Książka i Wiedza, Warszawa 1968.

Lipset S.M., Homo politicus. Społeczne podstawy polityki, Wydawnictwo Naukowe PWN, Warszawa 1995.

Ludność wiejska zwiazana z rolnictwem indywidualnym. Badania metodą reprezentacyjną. Stan w dniu 8 grudnia 1982 r., GUS, Warszawa 1983.

Łukasiewicz G., Kapitał ludzki organizacji. Pomiar i sprawozdawczość, Wydawnictwo Naukowe PWN, Warszawa 2009.

Nowicki J., Paradoks petnego zatrudnienia w Polsce, PWE, Warszawa 1989.

Orczyk J., Ekonomiczna interpretacja procesu ksztatcenia (propozycja modelowa), Kwartalnik Pedagogiczny 1985, $\mathrm{nr} 2$.

Pohoski M., Migracje ze wsi do miast. Studium wychodźstwa w latach 1945-1957 oparte na wynikach ankiety Instytutu Ekonomiki Rolnej, PWE, Warszawa 1963. 
Rocznik Statystyczny 1956, GUS, Warszawa 1956.

Rocznik Statystyczny 1958, GUS, Warszawa 1958.

Rocznik Statystyczny 1987, GUS, Warszawa 1987.

Stec R., Kwalifikacje zawodowe załogi huty aluminium, [w:] Dobrowolski K. Stojak A. (red.), Studia nad załoga huty aluminium w Skawinie, Wrocław 1969.

Szacunek rezerw wzrostu wydajności pracy w przemyśle wielkim i średnim (1953 r.), Archiwum Akt Nowych, PKPG, sygn. 330.

Widerszpil S., Skład polskiej klasy robotniczej. Tendencje zmian w okresie industrializacji socjalistycznej, PWN, Warszawa 1965.

Wieczorek-Szymańska A., Koncepcje kapitatu ludzkiego w teorii ekonomii-przegląd wybranych podejść, Studia i Prace Wydziału Nauk Ekonomicznych i Zarządzania 2010, nr 17.

Wystapienie E. Romera na I Sesji RNdZZO (30 lipca - 1 sierpnia 1945 r.), Archiwum Akt Nowych, Ministerstwo Ziem Odzyskanych, sygn. 1682.

Zaremba M., Wielka Trwoga Polska 1944-1947. Ludowa reakcja na kryzys, Znak, Kraków 2012. 